\title{
The Impact of Graves' Ophthalmopathy On Anterior and Posterior Ocular Structures: Ocular Imaging Based Study
}

\author{
(1) Hatice Selen Sönmez Kanar, ${ }^{1}$ (1) Murat Oklar,' (1) Ayşegül Penbe, \\ (D) Aysu Arsan, ${ }^{1}$ [1] Engin Ersin Şimşek²
}

\begin{abstract}
'Department of Ophthalmology, University of Health Science, Kartal Dr. Lütfi Kırdar Training and Research Hospital, ístanbul, Turkey

${ }^{2}$ Department of Family Medicine University of Health Science, Kartal Dr. Lütfi Kırdar Training and Research Hospital, Istanbul, Turkey

Submitted: 20.12 .2020 Accepted: 03.01.2021

Correspondence: Hatice Selen Sönmez Kanar, SBÜ, Kartal Dr. Lütfi Kırdar Eğitim ve Araştırma Hastanesi, Göz Hastalıkları Kliniği, İstanbul, Turkey E-mail: hselensonmez@hotmail.com
\end{abstract}

\begin{tabular}{|c|}
\hline 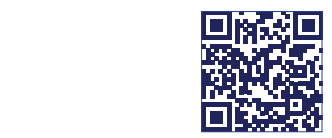 \\
\hline $\begin{array}{l}\text { Keywords: Graves' } \\
\text { ophthalmopathy; retinal } \\
\text { nerve fiber layer; spectral } \\
\text { domain optic coherence } \\
\text { tomography; subfoveal } \\
\text { choroidal thickness. }\end{array}$ \\
\hline (c) 08 \\
\hline
\end{tabular}

\begin{abstract}
Objective: The aim of our study was to evaluate the anterior and posterior ocular parameters in patients with Graves' ophthalmopathy (GO) compared to control.

Methods: Sixty-eight patients with GO and 40 healthy controls were included in the study. The patients with GO were divided into two groups according to their clinical activity score (CAS). Patients with $\geq 3 / 7$ CAS points were entitled as active $G O$ and CAS points less than $3 / 7$ were entitled as inactive GO. Spherical refractive error (SRE), astigmatic refractive error (ARE), central corneal thickness, intraocular pressure, and axial length (AL) were recorded. The subfoveal choroidal thickness (SFCT) and global and sectorial peripapillary retinal nerve fiber layer thickness ( $P R N F L T$ ) were measured by spectral domain- optical coherence tomography.
\end{abstract}

Results: The patients with active GO had significantly higher myopic SRE and ARE compared to patients with inactive GO and healthy controls ( $p=0.040$ and 0.030 , respectively). The mean AL was statistically significant taller in both GO groups than control $(p=0.048)$ but there were no significant differences in $A L$ between the patients with active $G O$ and inactive GO. Patients with active GO and inactive GO had significantly higher SFCT than controls $(p \leq 0.00 \mathrm{I})$. Furthermore, patients with active $\mathrm{GO}$ had significantly thinner global pRNFLT, superior $\mathrm{pRNFLT}$, inferior $\mathrm{PRNFLT}$, and temporal pRNFLT than patients with inactive GO and active GO. The patients with inactive GO had only thinner inferior PRNFLT compared to healthy controls.

Conclusion: The patients with GO had significant alterations in refractive status, SFCT, and pRNFLT, especially patients with active GO. These parameters might be potential adjuncts in the evaluation of GO patients and preventing ocular serious complications.

\section{INTRODUCTION}

Graves' disease (GD) is an autoimmune disorder that mostly affects women and can be presented with any thyroid hormone level, such as hyperthyroidism, hypothyroidism, and euthyroid. Graves' ophthalmopathy (GO) is the most common extra-thyroidal manifestation of the GD. ${ }^{[1]} \mathrm{GO}$ can be clinically seen in approximately $25-50 \%$ of patients with GD. ${ }^{[2]}$ Also a study reported that, subclinical GO in orbital imaging systems was detected in nearly $70 \%$ of patients with GD. ${ }^{[3]}$ Severe GO is not a frequent manifestation but may lead to sight-threatening complications including intense pain, corneal ulcerations, increased intraocular pressure (IOP), or compressive optic neuritis. ${ }^{[1]}$
The immunologic mechanism of GO is perivascular and diffuse infiltration of CD4+ and CD8+ T cells, B cells, plasma cells, and macrophages to adipose and fibrose tissue of orbit. This autoimmune activity leads to enlargement of the extraocular muscle and orbital adipose tissues. The extensive remodeling of ocular tissues may cause venous obstruction and congestion by mass effect. ${ }^{[4]}$

The choroidal network is the most vascular part of the eye and responsible for blood supply to outer segment of the retina. After the widely use of spectral domain optic coherence tomography (SD-OCT) technologies, the importance of choroidal thickness in the diagnosis and follow-up of many diseases has increased..$^{[5]}$ Furthermore, SD-OCT has enabled the quantitative measurement of 
choroid and retinal layers thicknesses or volume, in addition to obtaining cross-sectional images of choroid-retinal structures.

It is known that the GO can affect to various ocular structures. ${ }^{[3]}$ In this study, we aimed to evaluate refractive errors, subfoveal choroidal thickness (SFCT), and peripapillary retinal nerve fiber layer thickness ( $P R N F L T$ ), according to patients' GO severity and to compare with the healthy controls.

\section{MATERIALS AND METHODS}

This cross-sectional study was conducted in accordance with the tenets of the Declaration of Helsinki and written consents were obtained from all patients and controls. The study protocol was reviewed and approved by the institutional local ethics committee before the participants' enrollment (no: 514/188/7, date: 27.10.2020).

Seventy-eight patients with GO who were followed up our ophthalmology clinic, were in included the study. All participants were euthyroid in both clinical and laboratory assessments. Patients were divided into two groups according to their clinical activity score (CAS). ${ }^{[6]}$ Patients with $C A S \geq 3 / 7$ were classified as active $G O$, and those with CAS $\leq 2 / 7$ were classified as inactive GO. Age and gender matched 40 healthy controls were included in the study from the outpatient facility of the department. Exclusion criteria were listed as: Inflammatory orbital disease except GO, history of orbital radiotherapy, history of hormone therapy within 6 months, patients with greater than -6 or +3 diopters, and ocular disorders that effect RNFLT and SFCT (glaucoma, uveitis, optic neuritis, retinal vascular diseases, and choroidal diseases, etc.).

All participants were undergone detailed ophthalmic examination including spherical refractive error (SRE) and astigmatic refractive error (ARE) measurements with autorefractometry, best corrected visual acuity assessment with Snellen chart, IOP measurement with Goldman applanation tonometry, anterior segment examination with slit-lamp biomicroscopy, and dilated fundus examination. The proptosis was measured by the same examiner with Hertel exophthalmometry. The clinically worse eye of each patients with GO was selected for the study purpose. If both the eyes behaved similarly, a simple random selection was done to decide on the inclusive eye. The inclusive eye from the controls was randomly selected. The axial length $(\mathrm{AL})$ was measured with the IOL Master 500 (Carl Zeiss Meditec Inc., Jena, Germany).

The SFCT and the pRNFLT were measured by SD-OCT (Nikon RS-3000, Japan). All SD-OCT measurements were done by the same technician. All SFCT data, determined as the axial distance from the RPE to the outer choroid/ sclera interface, were assessed by the same ophthalmologist (HSK) using enhanced-depth imaging scans. The pRNFL thickness was measured by SD-OCT with a $3.46 \mathrm{~mm}$ in diameter scan circle centered on the optic disc. This provided the pRNFL thickness values for four quadrants
(N - Nasal, T - Temporal, S - Superior, and I - Inferior) and global mean values $\left(360^{\circ}\right)$.

\section{Statistical analysis}

All statistical analyses were performed using software IBM SPSS Statistics 21.0 version (SPSS, Inc., Chicago, IL, USA). Chi-square tests were used to analyze the categorical variables. The normality of the data was confirmed using the Kolmogorov-Smirnov test. Continuous variables were expressed as mean value \pm standard deviation. An independent Student's t-test and ANOVA were used to compare variables among groups. $\mathrm{P}<0.05$ was considered statistically significant. The sample size was calculated using $G$ Power 3.I.9.

\section{RESULTS}

Overall, 33 eyes of patients with active GO, 35 eyes of patients with inactive GO were included in the study and their data were compared with those of 40 age-matched healthy eyes of 40 controls. The mean age of the active GO group, inactive GO group, and controls was 38.12 \pm 8.81 years, $37.43 \pm 9.54$ years, and $36.60 \pm 7.66$ years, respectively $(p=0.027)$. Females were the majority in all groups and there was no statistical difference in gender distribution among the study groups $(p=0.36)$. Proptosis was presented more prominently in patients with active GO (19.67 $\mathrm{mm}$ ) compared to that presented in patients with inactive GO and controls ( $17.21 \mathrm{~mm}$ and $15.02 \mathrm{~mm}$, respectively; $\mathrm{p}<0.00 \mathrm{l})$.

In comparison of SRE and ARE, there were statistically significant difference among three groups $(p=0.040$ and $p=0.030$, respectively). The patients with active GO had significantly higher myopic SRE and ARE compared to patients with inactive GO and healthy controls. The mean $\mathrm{AL}$ was statistically significant taller in both $\mathrm{GO}$ groups than control $(p=0.048)$ but there were no significant differences in $A L$ between the patients with active $G O$ and inactive GO. There were no significant differences in IOP and central corneal thickness among the three groups ( $p=0.5 \mathrm{I}$ and 0.058 , respectively). Table I shows the clinical data of the three groups.

The mean SFCT was $358.40 \pm 41.44 \mu \mathrm{m}$ in patients with active GO, 334. I I $\pm 59.22 \mu \mathrm{m}$ in patients with inactive GO, and $305.2 \mathrm{I} \pm 65.50 \mu \mathrm{m}$ in controls. There was a statistically significant difference in SFCT among the three groups $(p<0.00 I)$. Both groups with GO had significantly thinner SFCT than healthy controls. Furthermore, patients with active GO had significantly thinner SFCT than patients with inactive $\mathrm{GO}$.

In post hoc analyses, the mean global PRNFLT of the patients with active GO $(99.94 \pm 8.7 \mathrm{I} \mu \mathrm{m})$ was significantly thinner than those of patients with inactive GO (104.92 \pm 6.48 $\mu \mathrm{m})$ and control $(\mathrm{I} 07.29 \pm 8.97 \mu \mathrm{m})(\mathrm{p}<0.00 \mathrm{I})$, while there were no statistically significant differences in global RNFLT between patients with inactive GO and controls ( $p>0.05)$. The patients with active GO had significantly lower $p R N$ - 
Table I. The comparison of anterior segment evaluations among the study groups

\begin{tabular}{|c|c|c|c|c|}
\hline & Patients with active $\mathbf{G O}(n=33)$ & Patients with inactive $\mathbf{G O}(n=35)$ & Controls $(n=40)$ & p-value \\
\hline SRE (D) & $-2.04 \pm 1.84^{\mathrm{a}, \mathrm{b}}$ & $-0.27 \pm 1.32$ & $-0.20 \pm 0.93$ & 0.040 \\
\hline ARE (D) & $-0.21 \pm 0.8^{3 a, b}$ & $-0.07 \pm 0.81$ & $0.21 \pm 0.54$ & 0.030 \\
\hline BCVA (decimal) & $0.98 \pm 0.8 \mathrm{I}$ & $0.99 \pm 0.40$ & $1.00 \pm 00$ & 0.121 \\
\hline CCT $(\mu \mathrm{m})$ & $524,44 \pm 36.9$ & $519.91 \pm 25.9$ & $526.80 \pm 26.2$ & 0.058 \\
\hline IOP $(\mathrm{mm} \mathrm{Hg})$ & $17.01 \pm 3.6$ & $16.62 \pm 2.3$ & $15.84 \pm 2.6$ & 0.51 \\
\hline $\mathrm{AL}(\mathrm{mm})$ & $23.13 \pm 0.7^{b}$ & $23.02 \pm 0.6^{c}$ & $22.65 \pm 0.7$ & 0.048 \\
\hline CAS point & $4.29 \pm 0.80$ & $0.97 \pm 0.78$ & N/A & $<0.001$ \\
\hline
\end{tabular}

Data are presented as mean \pm standard deviation. AL: Axial length; ARE: Astigmatic refractive error; BCVA: Best corrected visual acuity; CCT: Central corneal thickness; IOP: Intraocular pressure; SRE: Spherical refractive error. Post hoc analysis (Tukey): a Denotes statistical difference between active GO and inactive GO, ${ }^{b}$ Denotes statistical difference between active GO and control, 'Denotes statistical difference between inactive GO and control.

Table 2. The comparison of the SFCT and pRNFLT among the study groups

\begin{tabular}{lcccc}
\hline & Patients with active G0 $(\mathbf{n = 3 3 )}$ & Patients with inactive $\mathbf{G 0}(\mathbf{n}=35)$ & Controls $(\mathbf{n}=40)$ & p-value \\
\hline SCFT $(\mu \mathrm{m})$ & $358.40 \pm 41.44^{\mathrm{a}, \mathrm{b}}$ & $334.11 \pm 59.22^{\mathrm{c}}$ & $305.21 \pm 65.50$ & $<0.001$ \\
Global pRNFLT $(\mu \mathrm{m})$ & $99.94 \pm\left. 8.7\right|^{\mathrm{a}, \mathrm{b}}$ & $104.92 \pm 6.48$ & $107.29 \pm 8.97$ & $<0.001$ \\
S-pRNFLT $(\mu \mathrm{m})$ & $121.34 \pm 10.45^{\mathrm{a}, \mathrm{b}}$ & $126.47 \pm 9.65$ & $127.03 \pm 10.19$ & 0.011 \\
I-pRNFLT $(\mu \mathrm{m})$ & $118.24 \pm 12.23^{\mathrm{a}, \mathrm{b}}$ & $123.37 \pm 9.93^{\mathrm{c}}$ & $129.34 \pm 11.71$ & $<0.001$ \\
N-pRNFLT $(\mu \mathrm{m})$ & $79.94 \pm 11.02^{\mathrm{a}, \mathrm{b}}$ & $86.17 \pm 5.63$ & $87.62 \pm 6.21$ & 0.008 \\
T-pRNFLT $(\mu \mathrm{m})$ & $80.00 \pm 9.78^{\mathrm{b}}$ & $83.41 \pm 7.00$ & $85.24 \pm 5.32$ & 0.006 \\
\hline
\end{tabular}

Data are presented as mean \pm standard deviation. GO: Graves' ophthalmopathy; I: Inferior; N: Nasal; S: Superior; T: Temporal; pRNFLT: Peripapillary retinal nerve fiber layer thickness; SFCT: Subfoveal choroidal thickness. Post hoc analysis (Tukey): a Denotes statistical difference between active GO and inactive GO, ${ }^{b} D e n o t e s$

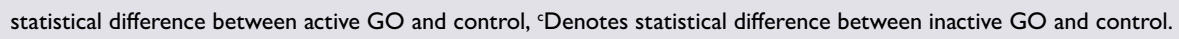

FLT in all quadrants than healthy control and lower superior, inferior, and nasal PRNFLT than patients with inactive GO. In comparison of quadrants of PRNFLT between patients with inactive GO and control, the statistically significant difference was observed only in inferior PRNFLT. Table 2 shows the comparison of the SFCT and PRNFLT among the study groups.

\section{DISCUSSION}

In this study, we assessed the anterior and posterior ocular segment alterations in patients with active and inactive GO. In GO pathogenesis, there is an enlargement of retrobulbar tissue and elongation of four rectus muscles. This condition may push the eyeball forward and cause the rectus muscles to pull the eyeball more strongly posterior. Moreover, the direction of the final vector on the eyeball results in a compressive force parallel to the visual axis, increasing the amplitude of the vector. This process may induce alteration of ocular $A L$ and the refractive error. Mombaerts et al. ${ }^{[7]}$ reported that GO was related to greater with the-rule corneal astigmatism and suggested that this was due to fibrosis of the soft tissue in the superolateral orbital region. Our findings suggested that, patients with active GO had higher myopic SRE and ARE and both patients with $\mathrm{GO}$ groups had higher AL compared to healthy controls. The previous studies revealed that patients with GO have more myopic refractive errors and it is related with exophthalmos levels. ${ }^{[8,9]}$ Furthermore, Kim et al. ${ }^{[10]}$ evaluated the ARE changes after orbital decompression surgery in patients with severe GO and they revealed that patients with orbital decompression had higher ARE than patients with GO without orbital decompression surgery. Another study reported that patients with GO who underwent orbital decompression showed myopic refractive change through increase in $A L$ and they added possible refractive changes should be considered in cases of GO complaining of decreased visual acuity after orbital decompression. ${ }^{[1]}$

The previous studies have reported that ocular blood flow was increased in patients with GO. Various techniques including Doppler imaging, ocular blood flow tonography, and oculo-dynamometry can ensure more reliable ocular blood flow measurements. ${ }^{[12,13]}$ More than $70 \%$ of the ocular blood flow goes to the choroidal network. ${ }^{[14]}$ The choroidal thickness might be affected in several systemic diseases. ${ }^{[5]}$ SD-OCT can provide non-invasive and quick evaluation of choroidal thickness. Özkan et al. ${ }^{[15]}$ reported that patients with GO had thicker SFCT than healthy controls in their study, which included patients with a 3 or more CAS points. Yu et al. ${ }^{[16]}$ evaluated the choroidal thickness in five sectorial region not only in subfoveal area and they revealed that choroidal thickness was higher in all region in patients with GO than controls. In our study, we found that patients with GO whether active or inactive 
had significantly higher SFCT than healthy controls. Furthermore, patients with active GO had significantly thicker SFCT than patients with inactive GO. These results suggested that SFCT increased in patients with GO according to their GO activity and increase in SFCT might be an indicator for retrobulbar vascular congestion.

Compressive optic neuropathy is one of the most serious complication of TO. The functional tests, such as color vision, contrast sensitivity, and visual field test, can be used for determining the for optic nerve damage, especially irreversible damages. The PRNFLT measurements with SDOCT provide valuable information for determination the viable retinal ganglion cell in the axonal mass and generally use for diagnosis of glaucoma and optic nerve diseases. ${ }^{[17]}$ The SD-OCT analyses are very useful in diagnosis of the patients with pre-perimetric glaucoma who have not any damage in visual field tests. In our study, patients with active GO had thinning in all PRNFLT quadrants compared to controls while patients with inactive $\mathrm{GO}$ had thinning in only inferior quadrants. Furthermore, patients with active GO had thinner global and quadrants pRNFLT than patients inactive GO except nasal pRNFLT. Similarly, Mugdha et al. ${ }^{[18]}$ found that patients with GO (who have $>3$ CAS points) had thinner global pRNFLT and thinner pRNFLT quadrants than controls and they found a significant thinning only in inferior pRNFLT during the 6 months followup. Yu et al. evaluated the patients with active and inactive GO using by optic coherence tomography angiography which is a newer technology, and they found that patients with active GO had thinner global PRNFLT, inferior, and temporal pRNFLT than patients inactive GO and controls. Therefore, early detection of thinning of pRNFLT might be useful for prevent irreversible optic nerve damage.

In this study, we divided patients with GO according to their CAS points. However, there are different disease severity classification systems for grading GO.[19] In our study, patients with active GO, with high CAS points, had significantly higher SFCT and lower pRNFLT. Cagiltay et al. ${ }^{[20]}$ evaluated the choroidal thickness in patients with GO and they used the VISA (vision, inflammation, strabismus, and appearance) inflammatory score system and they reported that the mean choroidal thickness was positively correlated with VISA score. Özkan et al. ${ }^{[15]}$ reported that SFCT was thicker in patients with higher CAS. On the other hand, Mugdha et al. ${ }^{[18]}$ did not found a relationship CAS points and PRNFLT. However, their patients' mean CAS scores were 1.95 and the distribution of CAS points were very limited. We believe that comparison of SDOCT parameters of the patients with higher CAS might give a better idea in relationship between CAS and SDOCT parameters.

Our study has some limitations. This study was a single center study with relatively small sample size. A manual method was used to measure SFCT; instead using an automated software program could be more reliable. Furthermore, only SD-OCT was performed, and optic disc perfusion was not evaluated. The use of ultrasound and/or optical coherence tomography angiography may be more reasonable for showing perfusion in future studies.

\section{CONCLUSION}

The patients with GO had significantly higher SFCT compared to healthy controls and patients with active GO had significantly thinner PRNFLT than patients with inactive GO and controls but only the inferior PRNFLT were significantly lower in patients with inactive GO. Screening by SD-OCT might be beneficial for preventing optic neuropathy and choroid-retinal diseases in patients with GO.

Funding

This study has no financial disclosure. Our clinical study has not been previously published and has not been submitted for publication elsewhere while under consideration.

\section{Ethics Committee Approval}

Approved by the local ethics committee (no: $514 / 188 / 7$, date: 27.10 .2020$)$.

\section{Peer-review}

\section{Internally peer-reviewed.}

Authorship Contributions

Concept: H.S.S.K., M.O.; Design: H.S.S.K.; Supervision: A.A., E.E.Ş.; Materials: E.E.Ş., M.O.; Data: H.S.S.K.; Analysis: H.S.S.K., A.P.; Literature search: A.P.; Writing: H.S.S.K.; Critical revision: A.A., E.E.Ş.

Conflict of Interest

None declared.

\section{REFERENCES}

1. Wiersinga WM, Bartalena L. Epidemiology and prevention of graves' ophthalmopathy. Thyroid 2002;12:855-60. [CrossRef]

2. Hwang S, Byun JW, Yoon JS, Lee EJ. Inhibitory effects of $\bigotimes$-lipoic acid on oxidative stress-induced adipogenesis in orbital fibroblasts from patients with graves ophthalmopathy. Medicine (Baltimore) 2016;95:e2497. [CrossRef]

3. Bahn RS. Graves' ophthalmopathy. N Engl J Med 2010;362:726-38.

4. McLachlan SM, Prummel MF, Rapoport B. Cell-mediated or humoral immunity in Graves' ophthalmopathy? Profiles of T-cell cytokines amplified by polymerase chain reaction from orbital tissue. J Clin Endocrinol Metab 1994;78:1070-4. [CrossRef]

5. Sezer T, Altınıșik M, Koytak İA, Özdemir MH. The choroid and optical coherence tomography. Turk J Ophthalmol 2016;46:30-7.

6. Luigi B, Lelio B, Alison D, Anja E, Pat K-T, Claudio M, et al. Consensus statement of the European Group on Graves' orbitopathy (EUGOGO) on management of GO. Eur J Endrocrinol 2008;158:273-85. [CrossRef]

7. Mombaerts I, Vandelanotte S, Koornneef L. Corneal astigmatism in Graves' ophthalmopathy. Eye 2006;20:440-6. [CrossRef]

8. Jankauskiene J, Jakstaite V, Smalinskas V. Changes of vision and refraction in patients with thyroid pathology. Medicina (Kaunas) 2009;45:378-81. [CrossRef]

9. Jankauskiene J, Jarusaitiene D. Assessment of visual acuity, refraction changes, and proptosis in different ages of patients with thyroid diseases. Int J Endocrinol 2012;2012:643275. [CrossRef] 
10. Kim SA, Jung SK, Paik JS, Yang S-W. Effect of orbital decompression on corneal topography in patients with thyroid ophthalmopathy. PLoS ONE 2015;10:e0133612. [CrossRef]

11. Kim WS, Chun YS, Cho BY, Lee JK. Biometric and refractive changes after orbital decompression in Korean patients with thyroidassociated orbitopathy. Eye 2016;30:400-5. [CrossRef]

12. Kurioka Y, Inaba M, Kawagishi T, Emoto M, Kumeda Y, Inoue $Y$, et al. Increased retinal blood flow in patients with Graves' disease: influence of thyroid function and ophthalmopathy. Eur J Endocrinol 2001;144:99-107. [CrossRef]

13. Walasik-Szemplińska D, Pauk-Domańska M, Sanocka U, Sudoł-Szopińska I. Doppler imaging of orbital vessels in the assessment of the activity and severity of thyroid-associated orbitopathy. J Ultrason 2015;15:388-97. [CrossRef]

14. Mrejen S, Spaide RF. Optical coherence tomography: Imaging of the choroid and beyond. Surv of Ophthalmol 2013;58:387-429. [CrossRef]

15. Özkan B, Koçer ÇA, Altintaş Ö, Karabaş L, Acar AZ, Yüksel N. Choroidal changes observed with enhanced depth imaging optical coherence tomography in patients with mild Graves orbitopathy. Eye 2016;30:917-24. [CrossRef]

16. Yu N, Zhang Y, Kang L, Gao Y, Zhang J, Wu Y. Analysis in choroidal thickness in patients with Graves' ophthalmopathy using spectral-domain optical coherence tomography. J Ophthalmol 2018;2018:3529395. [CrossRef]

17. Mwanza J-C, Oakley JD, Budenz DL, Anderson DR. Ability of cirrus HD-OCT optic nerve head parameters to discriminate normal from glaucomatous eyes. Ophthalmology 2011;118:241-8.e1. [CrossRef]

18. Mugdha K, Kaur A, Sinha N, Saxena S. Evaluation of retinal nerve fiber layer thickness profile in thyroid ophthalmopathy without optic nerve dysfunction. Int J Ophthalmol 2016;9:1634-7.

19. Savku E, Gündüz K. Diagnosis, follow-up and treatment results in thyroid ophthalmopathy. Turk J Ophthalmol 2015;45:156-63. [CrossRef]

20. Cagiltay E, Akay F, Demir O, Aydın E, Akmaz B, Pamuk B. The increment of choroidal thickness in euthyroid Graves' ophthalmopathy: is it an early sign of venous congestion? J Ophthalmol 2018;2018:5891531. [CrossRef]

\section{Graves' Oftalmopatisinin Oküler Ön ve Arka Segment Yapılarına Etkileri: Oküler Görüntüleme Temelli Çalışma}

Amaç: Çalışmamızın amacı Graves oftalmopatili (GO) hastalarda ön ve arka segment oküler parametreleri değerlendirmek ve sağııkı kontrol grubuyla karşılaştırmak.

Gereç ve Yöntem: Çalışmaya $68 \mathrm{GO}$ hastası ve 40 sağlıklı kontrol grubu dahil edildi. GO hastaları klinik aktivite skorlarına (KAD) göre iki gruba ayrıldı. KAD puanı $\geq 3 / 7$ olan hastalar aktif GO, 3/7'den az KAD puanları inaktif GO olarak adlandırıldı. Sferik kırılma kusuru (SKK), astigmatik kırılma kusuru (AKK), merkezi kornea kalınlığı, göz içi basıncı ve aksiyel uzunluk (AU) kaydedildi. Subfoveal koroidal kalınlık (SFKT) ve global ve sektörel peripapiller retina sinir lifi tabakası kalınlığı (pRSLTK) spektral alan-optik koherens tomografi ile ölçüldü.

Bulgular: Aktif GO hastaları, inaktif GO hastaları ve sağıklı kontrollere kıyasla anlamlı derecede daha yüksek miyopik SKK ve AKK'ye sahipti (sırasıyla, $p=0.040$ ve 0.030 ). Ortalama $A U$ değeri her iki $G O$ grubunda kontrole göre istatistiksel olarak anlamlı derecede daha uzundu $(p=0.048)$ ancak aktif $G O$ ve inaktif $G O$ olan hastalar arasında $A U$ açısından anlamlı fark yoktu. Aktif $G O$ ve inaktif $G O$ olan hastalar, kontrollere göre anlamlı derecede daha yüksek SFKK'ye sahipti $(p=<0.00 I)$. Ayrıca, aktif $G O$ 'lu hastalar, inaktif $G O$ ve aktif $G O$ hastalarına göre önemli ölçüde daha ince global pRSLTK, superio pRSLTK, inferior pRSLTK ve temporal pRSLTK'ye sahipti. İnaktif GO hastalarında sağlıklı kontrollere kıyasla sadece daha ince inferiyor pRSLTK vardı.

Sonuç: GO hastalarında, özellikle aktif GO olan hastalarda refraktif durumda, SFKK ve pRSLKT'de önemli değişiklikler saptandı. Bu parametreler GO hastalarının değerlendirilmesinde ve ciddi oküler komplikasyonların önlenmesinde potansiyel yardımcılar olabilir.

Anahtar Sözcükler: Graves' oftalmopati; retinal sinir lifi kalınlığ; spectral alan optic koherans tomografi; subfoveal koroidal kalınlık. 